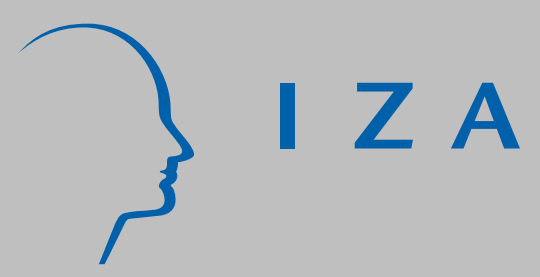

IZA DP No. 704

\title{
Intrafirm Mobility and Sex Differences in Pay
}

Michael Ransom

Ronald L. Oaxaca

J anuary 2003 


\title{
Intrafirm Mobility and Sex Differences in Pay
}

\author{
Michael Ransom \\ Brigham Young University \\ Ronald L. Oaxaca \\ University of Arizona and IZA Bonn \\ Discussion Paper No. 704
January 2003
}

IZA

P.O. Box 7240

D-53072 Bonn

Germany

Tel.: +49-228-3894-0

Fax: +49-228-3894-210

Email: iza@iza.org

This Discussion Paper is issued within the framework of IZA's research area Mobility and Flexibility of Labor. Any opinions expressed here are those of the author(s) and not those of the institute. Research disseminated by IZA may include views on policy, but the institute itself takes no institutional policy positions.

The Institute for the Study of Labor (IZA) in Bonn is a local and virtual international research center and a place of communication between science, politics and business. IZA is an independent, nonprofit limited liability company (Gesellschaft mit beschränkter Haftung) supported by the Deutsche Post AG. The center is associated with the University of Bonn and offers a stimulating research environment through its research networks, research support, and visitors and doctoral programs. IZA engages in (i) original and internationally competitive research in all fields of labor economics, (ii) development of policy concepts, and (iii) dissemination of research results and concepts to the interested public. The current research program deals with (1) mobility and flexibility of labor, (2) internationalization of labor markets, (3) welfare state and labor market, (4) labor markets in transition countries, (5) the future of labor, (6) evaluation of labor market policies and projects and (7) general labor economics.

IZA Discussion Papers often represent preliminary work and are circulated to encourage discussion. Citation of such a paper should account for its provisional character. A revised version may be available on the IZA website (www.iza.org) or directly from the author. 
IZA Discussion Paper No. 704

January 2003

\section{ABSTRACT \\ Intrafirm Mobility and Sex Differences in Pay}

In this paper we analyze eight years of employment data of a regional grocery store chain in the U.S. The data include job titles, wage rates, and earnings for all employees. We examine initial job assignments, mobility between departments, and mobility into supervisory and management positions in the firm. We model the flows of individuals between different departments and jobs within the firm as a Markov process. The estimated transition probabilities imply that expected seniority is greater for women. We find a pattern of intrafirm mobility and initial job assignment that generally penalizes women, even after taking account of individuals' characteristics.

JEL Classification: J3, J6

Keywords: job mobility, seniority, gender wage differentials

Corresponding author:

Ronald L. Oaxaca

Department of Economics

University of Arizona

P.O. Box 210108

Tucson, AZ 85721-0108

Tel.: +15206214135

Email: rlo@email.arizona.edu 


\section{INTRODUCTION}

A ubiquitous feature of the United States labor market is the segregation of men and women into different occupations and industries. An early paper by Oaxaca (1973) found that women tend to be in lower paying occupations. Some economists have argued that segregation of jobs into "men's work" and "women's work" is an essential element of labor market discrimination. The crowding hypothesis asserts that barriers that keep women from entering some jobs helps to maintain high wages for men, while forcing women to work for lower wages. Bergman (1986, Chapter 5) for example, stresses the role that segregation plays in reducing pay and advancement of women employees, especially within "internal" labor markets. Bielby and Baron (1984) examines how organizational structures and bureaucratic processes generate and sustain discrimination. Data based on 393 California establishments over the period 1959-79 indicated that segregation increases with establishment size and that establishment size accounts for most of the association between establishment characteristics and job segregation. Furthermore, the study observed that the scope for job segregation lessens with the female share of employment. Neuman and Oaxaca (2001) examines the effects of selection effects of occupational segregation on gender wage differentials among professional workers. Depending on how gender differences in the components on the selectivity terms are interpreted, estimates of gender discrimination can vary widely. Baldwin et al. (2001) identify the effects of occupational segregation on gender wage gaps using a model of hiearchical discrimination in which males have distaste for supervision by female managers. The model predicts that the relative proportion of female workers declines exponentially as one moves up the job ladder. Empirical results from a 1988 CPS sample of workers in the insurance industry support this prediction.

In this paper we take advantage of a unique data set to examine job placement 
and promotions within a firm. We follow job progression and pay of the firm's retail employees for a period of 10 years, from 1976 to 1986 . We find that the pattern of initial job placement and the promotion of female employees leads to a high level of segregation. This segregation also leads to lower pay for female employees.

\section{DATA}

The data on which this analysis is based come from a large grocery retailer in the United States. Table 1 briefly summarizes some of the characteristics of the firm during the period of our analysis. The firm operated between 55 and 60 retail stores, employing 2200 to 2500 workers in its retail operation. (We do not have data for nonretail employees, such as truck drivers, accountants or janitors.) About 60 percent of these stores were located within a single large metropolitan area. The company closed several stores and opened several new stores during this period.

The firm's employees have changed over the period of analysis. The proportion of employees who were women grew from about 36 percent to about 41 percent. Most employees worked part-time, but this changed rather dramatically over this period growing from $1 / 2$ to $3 / 4$ of all employees. Seniority (and to a lesser extent, age) of the typical employee increased over this period.

In the early 1980's several women initiated a class action lawsuit, alleging discrimination. The company lost the suit in 1984 and eventually reached a settlement in 1986. The settlement required the firm to pay several million dollars in "back pay" and also to initiate affirmative action policies for promotion and job assignment. We show later in this paper that this had a dramatic impact on segregation of women and men across jobs.

Figure 1 presents a simple organization chart for the company. Each store has three salaried employees - the store manager, the assistant manager, and the relief manager. All employees are covered by collective bargaining agreements. Most em- 
ployees are represented by the Retail Clerks Union, but meat department employees are represented by a separate union.

There are basically four "departments" in each store: meat, produce, grocery, and variety (non-foods). The produce and meat departments each have a manager. These managers are part of the collective bargaining unit, and they receive a higher wage than other employees. The night crew chief supervises stocking of the store during the night, and also receives a wage premium. The variety department does not have a manager. A few stores have specialized departments, such as a bakery; these employees are lumped together in the "other" category. Courtesy clerks bag and carry groceries for customers.

Table 2 provides summary statistics for the job categories shown in Figure 1. The average wage (or salary) is reported for each category, along with the average age, average seniority, and proportion who are female of individuals holding those jobs as of December 31, 1982. The average annual earnings are reported for employees who held the same job title on December 31, 1981. These annual earnings include bonuses paid to management employees. Most job titles encompass several different pay rates. Pay scales for clerks are based on seniority level. Scales may also vary slightly by location because the union contracts vary slightly from city to city.

Store level managers typically earn substantially more than other employees. However, the average earnings of the meat department manager are greater than the average earnings of the assistant or relief managers. Other meat department employees also receive relatively high wages compared with other departments.

Most employees in the store work as food clerks. This job includes those who stock shelves and those who operate cash registers. The average wage for food clerks was about $\$ 9$ per hour at the end of 1982 , excluding night shift or overtime premia. This was probably a fairly attractive wage for a job with no special education requirements. By comparison, the average wage of production workers in manufacturing in the 
United States for June, 1982 was $\$ 8.50 .^{1}$

Produce clerks and variety clerks also stock. Produce clerks have the same union wage scale as food clerks, but the variety clerks' scale is much lower. The average wage of variety clerks is $\$ 1.75$ per hour less than for produce clerks or food clerks. Courtesy clerks work for near the minimum wage. There is heavy turnover among courtesy clerks, with average seniority of only about one year. Courtesy clerks are about 10 years younger, on average, than food clerks or produce clerks.

\section{SEGREGATION AND WAGE DIFFERENTIALS}

The distribution of men and women across job titles is reported in Table 3. Job titles within this company are highly segregated. For example, the store level management and department management positions are occupied almost completely by male employees. (No woman had ever been a store manager for the firm as of December 31, 1982.) While 39 percent of the work force is composed of women, 95 percent of variety clerks and meat wrappers were women, but only 12 percent of produce clerks were women, and less than 1 percent of meat cutters were women. Courtesy clerk jobs are disproportionately filled by men.

A convenient way to summarize the level of segregation is to use the dissimilarity index, D. This index is widely attributed to Duncan and Duncan (1955), who describe some of its properties. The Duncan index is defined as

$$
D=\frac{1}{2} \sum_{i=1}^{K}\left|p_{i}^{m}-p_{i}^{f}\right|,
$$

where $p_{i}^{f}$ is the proportion of all females in job $i$, and $p_{i}^{m}$ is the proportion of all males in job $i$. The dissimilarity index is bounded between 0 and 1 . Proportional representation of men and women in all job categories would yield a value of 0 ; completely segregated categories would yield a value of $1 . D$ has a convenient interpretation it is equal to the fraction of women (or men) that would have to change jobs to have 
equal proportions of men and women in each job. In this case, about 46 percent of women would have to change jobs to achieve proportional representation in all

jobs. For other applications of the dissimilarity index to labor market segregation, see Albelda (1986) or Ransom (1990).

Table 4 reports the average characteristics of men and women in the various hourlypaid jobs. In most jobs, the average woman is paid more than the average man, reflecting the typically higher seniority and age of women employees. This is also demonstrated in Table 5.

Table 5 presents results of regression analysis of the natural logarithm of the hourly wage. (Salaried employees are excluded.) The first column shows that women's wages are about 8.5 percent higher than men's, on average. However, this difference is due to the higher seniority and age of women. Column 2 shows that after allowing for these differences, women's wages are actually about 8 percent less than the wages of similarly qualified men.

The third column of Table 5 includes indicators for the job title of the employee. Once these are included, the male/female wage difference falls to only about 1 percent. Thus, virtually all sex differences in pay can be explained by the job assignment of the employee. In fact, column IV shows that job title variables explain about 95 percent of all of the variation in wages. Of course, this result cannot be a surprise, since job titles are associated contractually with wage levels. But this analysis does point out that the substantial wage differential observed in column II is the result of segregation - women tend to be placed in low wage jobs relative to their seniority and age.

\section{INTRAFIRM MOBILITY}

The relatively disadvantageous job assignments for women can arise from two sources: (1) initial assignment at time of hire, and (2) promotions or other job changes 
during the employee's tenure at the firm. We will examine both of these issues using various models.

\section{$\underline{\text { A Markov Model of Mobility }}$}

One way to capture intrafirm job movements is with a simple Markov model. Assume that there are $K$ job categories. At any time, $t$, the proportion of employees in each category can be represented by a $1 \mathrm{x} K$ vector, $P_{t}$, where the $i t h$ element is $P_{i t}$. We are interested in examining both the relationship between $P_{t}$ and $P_{t-1}$, as well as the long run value of $P_{t}$ as $t$ becomes very large.

Central to this model is a matrix of transition probabilities. We define a $K \mathrm{x} K$ matrix, $A$, whose $i j t h$ element $a_{i j}$ represents the probability of moving from category $i$ in period $t-1$ to category $j$ in period $t$. The $i t h$ row contains the probabilities of moving from category $i$ in $t-1$ to each of the $K$ categories in period $t$. Thus, the elements of each row sum to 1 . If the job mobility process is stationary, then the following relationship must hold:

$$
P_{t}=P_{t-1} A
$$

In general, one can express $P_{t}$ in terms of an initial period job distribution and the transition matrix by backward recursion:

$$
P_{t}=P_{0} A^{t}
$$

The long-run distribution of employees across the $K$ categories, $P^{*}$ is independent of the initial distribution, and is defined by

$$
\lim _{t \rightarrow \infty}\left(P_{0} A^{t}\right)=P^{*}
$$

Without loss of generality, we designate the first row of the transition probability matrix $A$ as the transition probabilities corresponding to a new hire being assigned job 
titles 1 through $K$. We designate the first column of $A$ as the transition probabilities corresponding to an employment separation (quit, discharge, retirement) from job titles 1 through $K$. The steady state solution $P_{1}^{*}$ (the first element of $P^{*}$ ) may be interpreted as the probability that an employee would leave the company in any given period. Therefore, an employee's expected tenure equals $1 / P_{1}^{*}$.

Assuming that the long-run distribution is stationary, the solution for the elements of $P^{*}$ is obtained from

$$
P_{1}^{*}=1-\sum_{i=2}^{K} P_{i}^{*}
$$

and

$$
P_{j}^{*}=\sum_{i=1}^{K} a_{i j} P_{i}^{*} \text { for } j=2, \ldots, K .
$$

In matrix notation the steady state solution to the process may be expressed as

$$
\begin{gathered}
P^{*}=P^{*} \tilde{A}+b \\
\Rightarrow P^{*}=b\left(I_{K}-\tilde{A}\right)^{-1},
\end{gathered}
$$

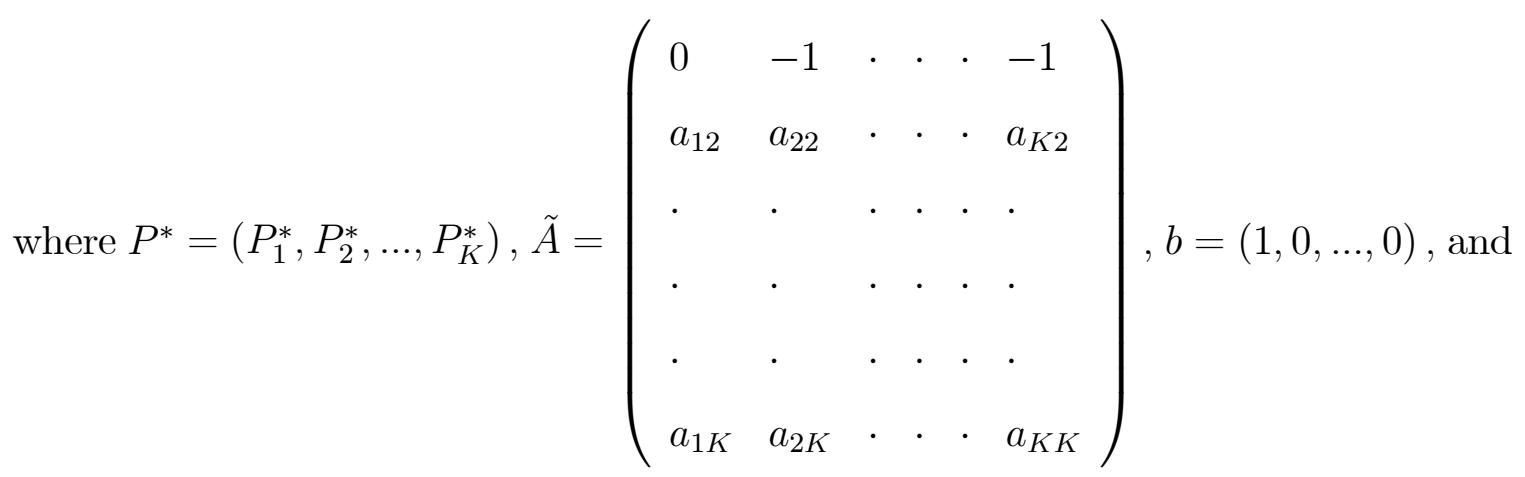
$I_{K}$ is an identity matrix of dimension $K$.

In our case, the elements of $A$ are estimated from observed transitions. We use the following estimator:

$$
\hat{a}_{i j}=\frac{\sum_{t=2}^{T} E_{i j t}}{\sum_{t=2}^{T} N_{i, t-1}}
$$


where $E_{i j t}$ is the number of employees in category $j$ in year $t$ who were in category $i$ in year $t-1$ and $N_{i, t-1}$ is the number of employees in category $i$ in year $t-1$. We have estimated these separately for men and women employees.

Tables 6.a and 6.b present our estimates of the transition matrices based on job titles held by employees as of year-end 1976, 1977, 1978, and 1979 transitions observed. The entries in the rows of the table show the disposition of the individuals who held the job title the previous year. For example, the second entry in the first column of Table 6.a shows that 8.45 percent of male store managers had separated from the company by the end of the next year. This matrix clearly shows the path to management $-3.9 \%$ of food clerks were promoted to night crew chief each year, while 18.5 percent of crew chiefs were promoted to relief manager, and 19.5 percent of relief managers were promoted to assistant manager, and 9.7 percent of assistant managers were promoted to store manager.

This table also shows why men are absent from some job titles. For example, the first row of the table shows that no men were hired as meat wrappers or variety clerks during the period. Those who held meat wrapper or variety clerk jobs at the beginning of the period left the company at a high rate.

Table 6.b offers a graphic explanation of the source of segregation. Many more entries in this matrix contain zeroes than in the corresponding male matrix. The largest fraction of women who are hired become food clerks, but about 7 percent of all hires become meat wrappers and about 6 percent become variety clerks. Of the food clerks, about 80 percent remain in the category each year and almost all of the remaining 20 percent leave the firm. Less than $3 / 10$ ths of 1 percent move to the crew chief position. $^{2}$

The glass ceilings are apparent in Table 6.b. Female variety clerks have about a 2 percent chance of becoming food clerks, otherwise they either remain variety clerk or leave the firm. Less than $1 / 2$ of 1 percent of meat wrappers move to a different 
position within the company each year. (Male meat department employees do not move to other parts of the store, either.)

The implications of these transition rates can be summarized by looking at the longrun job distribution for men and women. For the 1976-79 period the probabilities of a job separation were 0.218 and 0.197 for men and women, respectively. These probabilities imply an expected tenure of 4.6 years for men and 5.1 years for women. For the 1983-86 period, the probabilities of a job separation increased to 0.270 and 0.231 for men and women. Correspondingly, the expected tenure fell to 3.7 years for men and to 4.3 years for women. Therefore, the company could expect that women would stay with the firm on average a half-year longer than the men. Conditional upon remaining with the company, the steady state job title distribution is calculated according to $P_{j}^{*} /\left(1-P_{1}^{*}\right), j=2, \ldots, K$. Table 7 presents the long-run job title distribution for the 1976-79 data that are presented in Tables 6.a and 6.b, and also the long-run distribution implied by transitions observed between 1983 and 1986. The level of segregation implied, as measured by the dissimilarity index, falls dramatically from 0.562 to 0.325 . The law suit filed against the company in the early 1980's may have changed some of the employment practices of the firm.

\section{$\underline{\text { Regression Analysis of Mobility }}$}

One weakness of the preceding Markov model is that it fails to take account of differences in characteristics of men and women in the various job groups. While this is unlikely to explain much of the gender difference (due to the higher average qualifications of women in our sample), it is interesting to observe the patterns of mobility related to characteristics of individuals. The most interesting group to examine is the food clerks, since that category contains significant numbers of both men and women. This is also a step in the track from hire to store level management positions. ${ }^{3} \quad$ We concentrate on two aspects of mobility: (1) separations (voluntary), 
and (2) promotions into management positions.

Table 8 examines separation probabilities, using a probit regression model. We study the group of individuals present as food clerks as of December 31, 1978, and employees have separated if they do not appear as employees in 1982. The first column shows that women are much less likely than men to leave the firm which is consistent with the overall results of our Markov analysis. However, after controlling for age and seniority the difference among Food Clerks is not statistically significant. This contrasts with the conventional wisdom that women have higher quit propensities. Weiss' (1984) analysis also found lower quit rates for women. He argues that women should have lower quit rates if their opportunities outside the firm are generally inferior to men's. There is a strong correlation between age, seniority, and the separation rate, with the rate falling with age, and falling with seniority for the first 10 years. $^{4}$

In Table 9 we analyze the probability of a food clerk being promoted to a store level management position (store manager, assistant manager or relief manager). Again, we analyze employees who held the food clerk job as of December 31, 1978. The dependent variable in the analysis indicates whether the employee held a store level management job in 1982. (This will obviously understate the total number of promotions, since some managers may leave the company and others may be demoted in the intervening period.) Female food clerks are much less likely to be promoted, and the difference is statistically significant. Age and seniority do a poor job of identifying those who will be promoted.

\section{CONCLUSIONS}

In our analysis of the employment records of a single firm, we have found that there is a high level of segregation of jobs along gender lines. This segregation arises because some entry level jobs are assigned almost exclusively to women (and others to 
men), and because movements between jobs are much less likely to occur for women than for men. In particular, women were almost totally excluded from department level and store level management positions during the early years of our study. These rates were more favorable for women in the later years of our data, perhaps due to the "shock effect" of a class action lawsuit.

This segregation results in lower pay for women. Our analysis of hourly workers found that in 1982, women's wage rates were about 8 percent lower than men's, after controlling for age and seniority. ${ }^{5}$ This difference can be explained almost completely by the different job assignments for men and women. This measure clearly understates the pay gap due to segregation, since the predominantly male, high paying, store management positions are salaried, and thus are not included in this analysis.

Given a finding of gender inequity in the workplace, inquiry would naturally shift to the remedies that a firm or court of law should consider. In Oaxaca and Ransom (2000) several within-firm equity salary adjustment algorithms are developed. These algorithms are designed to satisfy various constraints such as total disbursement of the originally estimated aggregate salary inequity, invariance of the salaries of male workers with respect to a salary adjustment mechanism, the avoidance of salary reductions for women stemming from an adjustment mechanism, and positive lower bound constraints on salary adjustments for women. Simulations were run in which these salary adjustment algorithms were applied to a 1986 data set from the same company represented in the present study. Depending on which constraints are satisfied, the distribution of equity salary adjustments can be quite different. However, these algorithms beg the question of how they should be implemented. This is an important question in the light of this paper's findings that gender differences in job titles can be a major, if not the sole, reason for gender salary inequity. Pure salary adjustments without a program for short-term job reassignments and long-term equity in promotion and hiring is tantamount to a comparable worth solution. A solution 
along these lines most likely would distort the occupational wage structure. 


\section{End Notes}

* We gratefully acknowledge the helpful comments of seminar participants at the Universidad del Pais Vasco, Bilbao Spain. We also gratefully acknowledge the capable research assistance of Francesco Renna.

1. Source, Statistical Abstract of the United States, 1982-83 (103rd edition), Table 665.

2. Note that the fact that women crew chiefs present in one year always show up in the same job the next year presents a problem for our long-run analysis. We have assumed that no women will have the job title.

3. Positions such as variety clerk and meat wrapper show almost no mobility, so they do not present an interesting case for regression analysis.

4. Using a different functional form, we found that separation rates were about the same for those above about 25 years of age. Of course, separation rates among the youngest workers are extremely high.

5. Oaxaca and Ransom (1994) reports wage decompositions based on a 1986 sample from the same firm. Separate $(\log )$ earnings equations were estimated for males and females. Depending on the type of decomposition used, the unexplained earnings gap ranged from 28.8 percent to 33.1 percent in favor of men after accounting for age and seniority. Some of the unexplained gap may have resulted from different labor supply choices, but much had to do with job assignment. 


\section{REFERENCES}

Albelda, Randy P. (1986) "Occupational Segregation by Race and Gender, 19581981," Industrial and Labor Relations Review. 39(3): 404-411.

Baldwin et al. (2001) "A Hierarchical Theory of Occupational Segregation and Wage Discrimination," Economic Inquiry 39(1): 94-110.

Bergman, Barbara R. (1986) The Economic Emergence of Women. New York: Basic Books, Inc.

Bielby, William T. and James N. Baron (1984) "A Woman's Place Is With Other Women: Sex Segregation Within Organizations," In Sex Segregation in the Workplace, B. Reskin, ed., Washington: National Academy Press: 27-55.

Duncan, Otis D. and Beverly Duncan (1955) "A Methodological Analysis of Segregation Indexes," American Sociological Review. 10(2): 210-21\%.

Neuman, Shoshana and Ronald L. Oaxaca (April 2001) "Estimating Labor Market Discrimination with Selectivity-Corrected Wage Equations: Methodological Considerations and An Illustration from Israel," mimeo.

Oaxaca, Ronald (1973) "Male-Female Wage Differentials in Urban Labor Markets," International Economic Review. 14(3): 693-709.

Oaxaca, Ronald L. and Michael R Ransom (1994) "On Discrimination and the Decomposition of Wage Differentials," Journal of Econometrics. 61: 5-21.

Oaxaca, Ronald L. and Michael R Ransom (May 2000) "Using Econometric Models for Intrafirm Equity Salary Adjustments," mimeo.

Ransom, Michael R (1980) "Gender Segregation by Field in Higher Education," Research in Higher Education. 31(5): 477-494. 
Weiss, Andrew (1984) "Determinants of Quit Behavior," Journal of Labor Economics. 2(3): $371-87$. 


\section{Table 1}

\section{Company Characteristics}

Retail Operations

Selected Years (As of 31 December)

\begin{tabular}{|l|c|c|c|}
\hline & 1976 & 1982 & 1986 \\
\hline Number of Stores & 60 & 58 & 55 \\
Number of Stores in Largest & 35 & 36 & 32 \\
Metropolitan Area & 2,182 & 2,480 & 2,489 \\
Number of Retail Employees & $36.20 \%$ & $38.80 \%$ & $41.20 \%$ \\
$\begin{array}{l}\text { Percent of Employees who } \\
\text { are Female }\end{array}$ & $50.80 \%$ & $65.40 \%$ & $75.60 \%$ \\
$\begin{array}{l}\text { Percent of Employees who } \\
\text { work Part Time }\end{array}$ & 29.6 & 31 & 31.7 \\
Average Age & 4.5 & 5.9 & 6.3 \\
\hline Average Seniority & & & \\
\hline
\end{tabular}




\section{Table 2}

Characteristics of Job Holders

Year End, 1982

\begin{tabular}{|c|c|c|c|c|c|}
\hline Job Title & Variable & Mean & \begin{tabular}{c|} 
Standard \\
Deviation
\end{tabular} & Minimum & Maximum \\
\hline \multirow{5}{*}{$\begin{array}{l}\text { Store Manager } \\
\qquad(N=58)\end{array}$} & Weekly Salary & 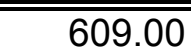 & 0 & $\bar{~} 609.00$ & 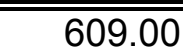 \\
\hline & Annual Earnings & $34,099.05$ & $3,859.89$ & $31,543.00$ & $44,204.10$ \\
\hline & Seniority & 15.61 & 8.23 & 0.38 & 34.12 \\
\hline & Age & 39.44 & 9.92 & 25.19 & 63.14 \\
\hline & Female & 0.00 & 0.00 & 0.00 & 0.00 \\
\hline \multirow{5}{*}{$\begin{array}{l}\text { Assistant Manager } \\
\quad(\mathrm{N}=58)\end{array}$} & Weekly Salary & 541.00 & 0.00 & 541.00 & 541.00 \\
\hline & \begin{tabular}{|l} 
Annual Earnings \\
\end{tabular} & $28,308.88$ & 386.64 & $27,536.00$ & $29,199.00$ \\
\hline & Seniority & 10.85 & 6.42 & 0.41 & 34.21 \\
\hline & Age & 33.34 & 8.68 & 21.97 & 54.97 \\
\hline & Female & 0.05 & 0.22 & 0.00 & 1.00 \\
\hline \multirow{5}{*}{$\begin{array}{l}\text { Relief Manager } \\
\qquad(N=57)\end{array}$} & Weekly Salary & 513.00 & 0.00 & 513.00 & 513.00 \\
\hline & Annual Earnings & $26,561.52$ & 146.16 & $26,147.00$ & $27,047.00$ \\
\hline & Seniority & 7.04 & 5.06 & 0.55 & 31.13 \\
\hline & Age & 30.16 & 9.44 & 20.30 & 58.44 \\
\hline & Female & 0.05 & 0.23 & 0.00 & 1.00 \\
\hline \multirow{5}{*}{$\begin{array}{c}\text { Food Clerk } \\
(\mathrm{N}=1,114)\end{array}$} & Hourly Wage & 9.06 & 0.99 & 5.58 & 9.55 \\
\hline & \begin{tabular}{|l} 
Annual Earnings \\
\end{tabular} & $17,222.82$ & 3199,21 & $3,283.58$ & $23,297.20$ \\
\hline & Seniority & 6.39 & 5.08 & 0.03 & 32.83 \\
\hline & Age & 33.36 & 11.76 & 17.72 & 65.02 \\
\hline & Female & 0.54 & 0.50 & 0.00 & 1.00 \\
\hline \multirow{5}{*}{$\begin{array}{l}\text { Night Crew Chief } \\
\quad(\mathrm{N}=56)\end{array}$} & Hourly Wage & 9.65 & 0.12 & 9.50 & 9.75 \\
\hline & Annual Earnings & $20,984.38$ & $1,391.08$ & $17,841.61$ & $24,153.07$ \\
\hline & Seniority & 6.32 & 3.98 & 0.50 & 22.34 \\
\hline & Age & 29.68 & 8.97 & 20.54 & 56.83 \\
\hline & Female & 0.05 & 0.23 & 0.00 & 1.00 \\
\hline \multirow{5}{*}{$\begin{array}{l}\text { Courtesy Clerk } \\
\qquad(N=568)\end{array}$} & Hourly Wage & 3.19 & 0.29 & 2.85 & 3.60 \\
\hline & Annual Earnings & $4,859.61$ & $1,408.86$ & $1,760.35$ & $9,761.70$ \\
\hline & Seniority & 0.90 & 0.83 & 0.02 & 4.40 \\
\hline & Age & 19.16 & 4.62 & 16.09 & 72.63 \\
\hline & Female & 0.29 & 0.46 & 0.00 & 1.00 \\
\hline \multirow{5}{*}{$\begin{array}{l}\text { Produce Manager } \\
\qquad(\mathrm{N}=58)\end{array}$} & Hourly Wage & 9.85 & 0.10 & 9.65 & 10.01 \\
\hline & Annual Earnings & $23,454.38$ & $1,108.86$ & $18,900.44$ & $25,165.37$ \\
\hline & \begin{tabular}{|l} 
Seniority \\
\end{tabular} & 14.64 & 8.61 & 2.17 & 31.90 \\
\hline & Age & 36.29 & 9.86 & 20.04 & 56.61 \\
\hline & Female & 0.00 & 0.00 & 0.00 & 0.00 \\
\hline
\end{tabular}


Table 2 (con't)

Characteristics of Job Holders

Year End, 1982

\begin{tabular}{|c|c|c|c|c|c|}
\hline Job Title & Variable & Mean & \begin{tabular}{c|} 
Standard \\
Deviation
\end{tabular} & Minimum & Maximum \\
\hline \multirow{5}{*}{$\begin{array}{l}\text { Produce Clerk } \\
\qquad(\mathrm{N}=109)\end{array}$} & Hourly Wage & 8.95 & 1.13 & 5.58 & 9.55 \\
\hline & Annual Earnings & $17,899.87$ & $3,478.52$ & $7,811.48$ & $22,281.83$ \\
\hline & Seniority & 6.61 & 6.62 & 0.22 & 32.78 \\
\hline & Age & 30.21 & 10.39 & 16.73 & 61.89 \\
\hline & Female & 0.12 & 0.33 & 0.00 & 0.00 \\
\hline \multirow{5}{*}{$\begin{array}{l}\text { Meat Manager } \\
\quad(N=57)\end{array}$} & Hourly Wage & 11.64 & 0.09 & 11.29 & 11.67 \\
\hline & Annual Earnings & $29,147.17$ & $1,572.17$ & $25,116.82$ & $32,309.71$ \\
\hline & \begin{tabular}{|l|} 
Seniority \\
\end{tabular} & 11.43 & 7.43 & 1.42 & 29.08 \\
\hline & \begin{tabular}{|l} 
Age \\
\end{tabular} & 40.65 & 9.05 & 27.21 & 64.48 \\
\hline & Female & 0.00 & 0.00 & 0.00 & 0.00 \\
\hline \multirow{5}{*}{$\begin{array}{l}\text { Meat Cutter } \\
(\mathrm{N}=168)\end{array}$} & Hourly Wage & 11.28 & 0.33 & 7.20 & 11.33 \\
\hline & Annual Earnings & $24,523.44$ & $2,652.64$ & $3,212.41$ & $28,909.21$ \\
\hline & Seniority & 7.19 & 5.87 & 0.41 & 28.64 \\
\hline & Age & 41.36 & 11.01 & 23.11 & 65.98 \\
\hline & Female & 0.01 & 0.08 & 0.00 & 1.00 \\
\hline \multirow{5}{*}{$\begin{array}{l}\text { Meat Wrapper } \\
\quad(\mathrm{N}=89)\end{array}$} & Hourly Wage & 10.28 & 0.27 & 9.07 & 10.40 \\
\hline & Annual Earnings & $18,758.66$ & $4,164.13$ & $2,156.20$ & $24,197.57$ \\
\hline & Seniority & 8.33 & 6.88 & 0.23 & 26.00 \\
\hline & Age & 41.90 & 11.42 & 20.47 & 64.84 \\
\hline & Female & 0.97 & 0.18 & 0.00 & 1.00 \\
\hline \multirow{5}{*}{$\begin{array}{c}\text { Variety Clerk } \\
\quad(\mathrm{N}=78)\end{array}$} & Hourly Wage & 7.26 & 0.96 & 5.39 & 8.64 \\
\hline & Annual Earnings & $13,132.72$ & $2,410.48$ & $7,736.17$ & $17,021.99$ \\
\hline & Seniority & 6.42 & 4.67 & 0.16 & 16.31 \\
\hline & Age & 32.69 & 12.63 & 16.71 & 63.34 \\
\hline & Female & 0.95 & 0.22 & 0.00 & 1.00 \\
\hline \multirow{5}{*}{$\begin{array}{l}\text { Other } \\
(N=13)\end{array}$} & Hourly Wage & 6.55 & 0.95 & 5.58 & 8.47 \\
\hline & Annual Earnings & $11,659.68$ & $3,074.14$ & $7,674.86$ & $18,272.61$ \\
\hline & \begin{tabular}{|l|} 
Seniority \\
\end{tabular} & 5.86 & 5.59 & 0.24 & 18.96 \\
\hline & Age & 36.28 & 15.57 & 18.05 & 62.08 \\
\hline & Female & 0.77 & 0.44 & 0.00 & 1.00 \\
\hline
\end{tabular}




\section{Table 3}

Distribution of Men and Women Across Jobs in 1982

\begin{tabular}{|l|r|r|r|r|}
\hline & $\begin{array}{c}\text { Women } \\
\text { Holding } \\
\text { Title }\end{array}$ & $\begin{array}{c}\text { Fraction } \\
\text { of All } \\
\text { Women }\end{array}$ & $\begin{array}{c}\text { Men } \\
\text { Holding } \\
\text { Title }\end{array}$ & $\begin{array}{c}\text { Fraction } \\
\text { of All } \\
\text { Men }\end{array}$ \\
\hline \hline Store Manager & 0 & 0.000 & 58 & 0.038 \\
\hline Assistant Manager & 3 & 0.003 & 55 & 0.036 \\
\hline Relief Manager & 3 & 0.003 & 55 & 0.036 \\
\hline Food Clerk & 599 & 0.623 & 507 & 0.334 \\
\hline Night Crew Chief & 3 & 0.003 & 53 & 0.035 \\
\hline Courtesy Clerk & 170 & 0.177 & 403 & 0.265 \\
\hline Produce Manager & 0 & 0.000 & 58 & 0.038 \\
\hline Produce Clerk & 13 & 0.014 & 96 & 0.063 \\
\hline Meat Manager & 0 & 0.000 & 57 & 0.038 \\
\hline Meat Cutter & 1 & 0.001 & 167 & 0.110 \\
\hline Meat Wrapper & 86 & 0.089 & 3 & 0.002 \\
\hline Variety Clerk & 74 & 0.077 & 4 & 0.003 \\
\hline Other & 10 & 0.010 & 3 & 0.002 \\
\hline \hline Total & 962 & 1.000 & 1518 & 1.000 \\
\hline
\end{tabular}




\section{Table 4}

Average Characteristics of Employees in Hourly-Paid Jobs, By Sex

(December 31, 1982)

\begin{tabular}{|c|c|c|c|}
\hline Job Title & Variable & $\begin{array}{c}\text { Average } \\
\text { Male }\end{array}$ & $\begin{array}{c}\text { Average } \\
\text { Female }\end{array}$ \\
\hline \multirow[t]{3}{*}{ Food Clerk } & Wage & 9.03 & 9.09 \\
\hline & eniority & 5.84 & $6.8 \varepsilon$ \\
\hline & Age & 27.9 & 37.99 \\
\hline \multirow[t]{3}{*}{ Night Crew Chief } & Wage & 9.66 & 9.58 \\
\hline & Seniority & 6.10 & 10.35 \\
\hline & Age & 29.03 & 41.17 \\
\hline \multirow[t]{3}{*}{ Courtesy Clerk } & Wage & 3.17 & 3.23 \\
\hline & Seniority & 0.90 & 0.99 \\
\hline & Age & 18.95 & 19.41 \\
\hline \multirow[t]{3}{*}{ Produce Manager } & Wage & 9.85 & - \\
\hline & Seniority & 14.64 & - \\
\hline & Age & 36.29 & - \\
\hline \multirow[t]{3}{*}{ Produce Clerk } & Wage & 9.02 & $8.4 \varepsilon$ \\
\hline & Seniority & 7.10 & 2.95 \\
\hline & Age & 30.56 & 27.65 \\
\hline \multirow[t]{3}{*}{ Meat Manager } & Wage & 11.64 & - \\
\hline & Seniority & 11.43 & - \\
\hline & Age & 40.65 & - \\
\hline \multirow{3}{*}{ Meat Cutter } & Wage & 11.28 & 11.33 \\
\hline & Seniority & 7.22 & 1.47 \\
\hline & Age & 41.44 & 28.7 \\
\hline \multirow[t]{3}{*}{ Meat Wrapper } & Wage & 9.76 & 10. \\
\hline & Seniority & 2.15 & 8.5 \\
\hline & Age & 21.25 & 42.63 \\
\hline \multirow[t]{3}{*}{ Variety Clerk } & Wage & 5.71 & 7.3 \\
\hline & Seniority & 2.15 & 8.55 \\
\hline & Age & 18.31 & 33.47 \\
\hline \multirow[t]{3}{*}{ Other } & Wage & 5.81 & 6.77 \\
\hline & Seniority & 2.43 & 6.8 \\
\hline & Age & 29.33 & 38.37 \\
\hline
\end{tabular}




\section{Table 5}

Regression Results, Hourly Workers 1982 Dependent Variable is Logarithm of Hourly Wage

(Standard Errors are in Parentheses)

\begin{tabular}{|c|c|c|c|c|}
\hline & $\underline{1}$ & II & III & $\underline{\underline{I V}}$ \\
\hline Intercept & 1.926 & -0.221 & 0.870 & 1.152 \\
\hline & $(0.013)$ & $(0.047)$ & $(0.018)$ & $(0.005)$ \\
\hline Female & 0.084 & -0.078 & -0.013 & 0.011 \\
\hline & $(0.020)$ & $(0.012)$ & $(0.005)$ & $(0.005)$ \\
\hline Seniority & - & $\begin{array}{r}0.065 \\
(0.003)\end{array}$ & $\begin{array}{r}0.019 \\
(0.001)\end{array}$ & - \\
\hline$(\text { Seniority })^{2}$ & - & $\begin{array}{r}-2.25 \mathrm{e}-03 \\
(1.26 \mathrm{e}-04)\end{array}$ & $\begin{array}{r}-6.23 e-04 \\
(4.60 e-05)\end{array}$ & - \\
\hline Age & - & $\begin{array}{r}0.111 \\
(0.003)\end{array}$ & $\begin{array}{r}0.019 \\
(0.001)\end{array}$ & - \\
\hline$(\text { Age })^{2}$ & - & $\begin{array}{r}-1.30 \mathrm{e}-03 \\
(3.04 \mathrm{e}-05)\end{array}$ & $\begin{array}{r}-2.19 \mathrm{e}-04 \\
(1.61 \mathrm{e}-05)\end{array}$ & - \\
\hline Food Clerk & - & - & $\begin{array}{r}0.903 \\
(0.007)\end{array}$ & $\begin{array}{r}1.039 \\
(0.006)\end{array}$ \\
\hline Night Crew Chief & - & - & $\begin{array}{r}0.966 \\
(0.015)\end{array}$ & $\begin{array}{r}1.115 \\
(0.015)\end{array}$ \\
\hline Produce Manager & - & - & $\begin{array}{r}0.946 \\
(0.015)\end{array}$ & $\begin{array}{r}1.135 \\
(0.015)\end{array}$ \\
\hline Produce Clerk & - & - & $\begin{array}{r}0.900 \\
(0.011)\end{array}$ & $\begin{array}{r}1.029 \\
(0.011)\end{array}$ \\
\hline Meat Manager & - & - & $\begin{array}{r}1.100 \\
(0.015)\end{array}$ & $\begin{array}{r}1.303 \\
(0.015)\end{array}$ \\
\hline Meat Cutter & - & - & $\begin{array}{r}1.100 \\
(0.015)\end{array}$ & $\begin{array}{r}1.303 \\
(0.015)\end{array}$ \\
\hline Meat Wrapper & - & - & $\begin{array}{r}1.014 \\
(0.013)\end{array}$ & $\begin{array}{r}1.167 \\
(0.013)\end{array}$ \\
\hline Variety Clerk & - & - & $\begin{array}{r}0.689 \\
(0.013)\end{array}$ & $\begin{array}{r}0.811 \\
(0.014)\end{array}$ \\
\hline Other & - & - & $\begin{array}{r}0.596 \\
(0.027)\end{array}$ & $\begin{array}{r}0.710 \\
(0.031)\end{array}$ \\
\hline Courtesy Clerk & - & - & . & - \\
\hline $\mathrm{R}^{2}$ & 0.007 & 0.676 & 0.961 & 0.949 \\
\hline
\end{tabular}


Table 6.a.

Transition Probabilities - Male Employees

December 31, 1976 - December 31, 1979

\begin{tabular}{|c|c|c|c|c|c|c|c|c|c|c|c|c|c|c|}
\hline \multirow[b]{2}{*}{$\begin{array}{c}\text { Source } \\
\text { Category }\end{array}$} & \multicolumn{14}{|c|}{ Destination Category } \\
\hline & Terminated & $\begin{array}{c}\text { Store } \\
\text { Manager }\end{array}$ & $\begin{array}{l}\text { Assistant } \\
\text { Manager }\end{array}$ & $\begin{array}{c}\text { Relief } \\
\text { Manager }\end{array}$ & $\begin{array}{l}\text { Food } \\
\text { Clerk }\end{array}$ & $\begin{array}{l}\text { Crew } \\
\text { Chief }\end{array}$ & $\begin{array}{c}\text { Courtesy } \\
\text { Clerk }\end{array}$ & $\begin{array}{l}\text { Produce } \\
\text { Manager }\end{array}$ & $\begin{array}{c}\text { Produce } \\
\text { Clerk }\end{array}$ & $\begin{array}{c}\text { Meat } \\
\text { Manager }\end{array}$ & $\begin{array}{l}\text { Meat } \\
\text { Cutter }\end{array}$ & $\begin{array}{c}\text { Meat } \\
\text { Wrapper }\end{array}$ & $\begin{array}{c}\text { Variety } \\
\text { Clerk }\end{array}$ & Other \\
\hline New Hires & 0 & 0.0026 & 0.0013 & 0.0086 & 0.205 & 0.0086 & 0.6839 & 0.002 & 0.0271 & 0.0007 & 0.0602 & 0 & 0 & 0 \\
\hline $\begin{array}{l}\text { Store } \\
\text { Manager }\end{array}$ & 0.0847 & 0.8701 & 0.0282 & 0 & 0.0113 & 0 & 0 & 0.0056 & 0 & 0 & 0 & 0 & 0 & 0 \\
\hline $\begin{array}{l}\text { Assistant } \\
\text { Manager }\end{array}$ & 0.1257 & 0.0971 & 0.7371 & 0.0229 & 0.0171 & 0 & 0 & 0 & 0 & 0 & 0 & 0 & 0 & 0 \\
\hline $\begin{array}{l}\text { Relief } \\
\text { Manager }\end{array}$ & 0.1379 & 0 & 0.1954 & 0.6207 & 0.0402 & 0 & 0 & 0.0057 & 0 & 0 & 0 & 0 & 0 & 0 \\
\hline $\begin{array}{l}\text { Food } \\
\text { Clerk }\end{array}$ & 0.2277 & 0.0008 & 0.0024 & 0.0295 & 0.6561 & 0.039 & 0.0247 & 0.0024 & 0.0175 & 0 & 0 & 0 & 0 & 0 \\
\hline $\begin{array}{l}\text { Crew } \\
\text { Chief }\end{array}$ & 0.1481 & 0 & 0 & 0.1852 & 0.1852 & 0.463 & 0 & 0 & 0.0185 & 0 & 0 & 0 & 0 & 0 \\
\hline $\begin{array}{l}\text { Courtesy } \\
\text { Clerk }\end{array}$ & 0.6487 & 0 & 0 & 0 & 0.1377 & 0.0024 & 0.1733 & 0 & 0.0364 & 0 & 0.0016 & 0 & 0 & 0 \\
\hline $\begin{array}{l}\text { Produce } \\
\text { Manager }\end{array}$ & 0.0457 & 0 & 0.0057 & 0.0057 & 0 & 0 & 0 & 0.88 & 0.0629 & 0 & 0 & 0 & 0 & 0 \\
\hline $\begin{array}{l}\text { Produce } \\
\text { Clerk } \\
\end{array}$ & 0.1709 & 0 & 0 & 0.0028 & 0.1289 & 0 & 0.0112 & 0.0364 & 0.6471 & 0 & 0.0028 & 0 & 0 & 0 \\
\hline $\begin{array}{l}\text { Meat } \\
\text { Manager }\end{array}$ & 0.0629 & 0 & 0 & 0 & 0 & 0 & 0 & 0 & 0 & 0.8914 & 0.0457 & 0 & 0 & 0 \\
\hline $\begin{array}{l}\text { Meat } \\
\text { Cutter }\end{array}$ & 0.1111 & 0 & 0 & 0 & 0 & 0 & 0 & 0 & 0.0025 & 0.042 & 0.8444 & 0 & 0 & 0 \\
\hline $\begin{array}{l}\text { Meat } \\
\text { Wrapper }\end{array}$ & 1 & 0 & 0 & 0 & 0 & 0 & 0 & 0 & 0 & 0 & 0 & 0 & 0 & 0 \\
\hline $\begin{array}{l}\text { Variety } \\
\text { Clerk }\end{array}$ & 0.4 & 0 & 0 & 0 & 0 & 0 & 0 & 0 & 0 & 0 & 0 & 0 & 0.6 & 0 \\
\hline Other & 0.3333 & 0 & 0 & 0 & 0 & 0 & 0.333 & 0 & 0 & 0 & 0 & 0 & 0 & 0.333 \\
\hline
\end{tabular}


Table 6.b.

Transition Probabilities - Female Employees

December 31, 1976 - December 31, 1979

\begin{tabular}{|c|c|c|c|c|c|c|c|c|c|c|c|c|c|c|}
\hline \multirow[b]{2}{*}{$\begin{array}{c}\text { Source } \\
\text { Category }\end{array}$} & \multicolumn{14}{|c|}{ Destination Category } \\
\hline & Terminated & $\begin{array}{c}\text { Store } \\
\text { Manager }\end{array}$ & $\begin{array}{l}\text { Assistant } \\
\text { Manager } \\
\end{array}$ & \begin{tabular}{c|} 
Relief \\
Manager \\
\end{tabular} & $\begin{array}{l}\text { Food } \\
\text { Clerk }\end{array}$ & $\begin{array}{l}\text { Crew } \\
\text { Chief } \\
\end{array}$ & $\begin{array}{c}\text { Courtesy } \\
\text { Clerk } \\
\end{array}$ & $\begin{array}{l}\text { Produce } \\
\text { Manager }\end{array}$ & $\begin{array}{c}\text { Produce } \\
\text { Clerk }\end{array}$ & $\begin{array}{c}\text { Meat } \\
\text { Manager }\end{array}$ & $\begin{array}{l}\text { Meat } \\
\text { Cutter }\end{array}$ & $\begin{array}{c}\text { Meat } \\
\text { Wrapper }\end{array}$ & $\begin{array}{c}\text { Variety } \\
\text { Clerk }\end{array}$ & Other \\
\hline New Hires & 0 & 0 & 0 & 0 & 0.4627 & 0 & 0.4004 & 0 & 0.0044 & 0 & 0 & 0.069 & 0.0567 & 0.0067 \\
\hline \begin{tabular}{|l} 
Store \\
Manager
\end{tabular} & 0 & 0 & 0 & 0 & 0 & 0 & 0 & 0 & 0 & 0 & 0 & 0 & 0 & 0 \\
\hline $\begin{array}{l}\text { Assistant } \\
\text { Manager }\end{array}$ & 0 & 0 & 0 & 0 & 0 & 0 & 0 & 0 & 0 & 0 & 0 & 0 & 0 & 0 \\
\hline \begin{tabular}{|l} 
Relief \\
Manager \\
\end{tabular} & 1 & 0 & 0 & 0 & 0 & 0 & 0 & 0 & 0 & 0 & 0 & 0 & 0 & 0 \\
\hline $\begin{array}{l}\text { Food } \\
\text { Clerk }\end{array}$ & 0.1895 & 0 & 0 & 0.0006 & 0.804 & 0.0026 & 0.0019 & 0 & 0.0006 & 0 & 0 & 0 & 0.0006 & 0 \\
\hline $\begin{array}{l}\text { Crew } \\
\text { Chief } \\
\end{array}$ & 0 & 0 & 0 & 0 & 0 & 1 & 0 & 0 & 0 & 0 & 0 & 0 & 0 & 0 \\
\hline \begin{tabular}{|l|} 
Courtesy \\
Clerk \\
\end{tabular} & 0.6122 & 0 & 0 & 0 & 0.1749 & 0 & 0.1574 & 0 & 0.0117 & 0 & 0 & 0.0058 & 0.0379 & 0 \\
\hline $\begin{array}{l}\text { Produce } \\
\text { Manager }\end{array}$ & 0 & 0 & 0 & 0 & 0 & 0 & 0 & 0 & 0 & 0 & 0 & 0 & 0 & 0 \\
\hline \begin{tabular}{|l} 
Produce \\
Clerk \\
\end{tabular} & 0.2500 & 0 & 0 & 0 & 0.2500 & 0 & 0.125 & 0 & 0.375 & 0 & 0 & 0 & 0 & 0 \\
\hline $\begin{array}{l}\text { Meat } \\
\text { Manager }\end{array}$ & 0 & 0 & 0 & 0 & 0 & 0 & 0 & 0 & 0 & 0 & 0 & 0 & 0 & 0 \\
\hline $\begin{array}{l}\text { Meat } \\
\text { Cutter }\end{array}$ & 0 & 0 & 0 & 0 & 0 & 0 & 0 & 0 & 0 & 0 & 0 & 0 & 0 & 0 \\
\hline \begin{tabular}{|l|} 
Meat \\
Wrapper
\end{tabular} & 0.1853 & 0 & 0 & 0 & 0 & 0 & 0.0035 & 0 & 0 & 0 & 0 & 0.8112 & 0 & 0 \\
\hline $\begin{array}{l}\text { Variety } \\
\text { Clerk }\end{array}$ & 0.2222 & 0 & 0 & 0 & 0.0206 & 0 & 0.0041 & 0 & 0 & 0 & 0 & 0 & 0.7531 & 0 \\
\hline Other & 0.3235 & 0 & 0 & 0 & 0 & 0 & 0 & 0 & 0 & 0 & 0 & 0,0294 & 0 & 0.6471 \\
\hline
\end{tabular}




\section{Table 7}

Long-Run Job Distributions From Markov Model

\begin{tabular}{|lrrrr|}
\hline & \multicolumn{2}{c}{$\begin{array}{c}\text { Based On } \\
1976-79 \\
\text { Transitions }\end{array}$} & \multicolumn{2}{c|}{$\begin{array}{c}\text { Based On } \\
1983-86 \\
\text { Transitions }\end{array}$} \\
\hline \hline Job Title & Males & Females & Male & Female \\
\hline Store Manager & 0.041 & 0.000 & 0.025 & 0.007 \\
Assistant Manager & 0.045 & 0.000 & 0.020 & 0.012 \\
Relief Manager & 0.045 & 0.000 & 0.022 & 0.016 \\
Food Clerk & 0.313 & 0.700 & 0.323 & 0.583 \\
Night Crew Chief & 0.028 & 0.000 & 0.035 & 0.003 \\
Courtesy Clerk & 0.240 & 0.120 & 0.371 & 0.267 \\
Produce Manager & 0.037 & 0.000 & 0.032 & 0.000 \\
Produce Clerk & 0.071 & 0.005 & 0.063 & 0.020 \\
Meat Manager & 0.051 & 0.000 & 0.019 & 0.000 \\
Meat Cutter & 0.126 & 0.000 & 0.056 & 0.003 \\
Meat Wrapper & 0.000 & 0.094 & 0.003 & 0.011 \\
Variety Clerk & 0.000 & 0.076 & 0.005 & 0.051 \\
Other & 0.000 & 0.005 & 0.016 & 0.027 \\
Retail Operations & 0.000 & 0.000 & 0.010 & 0.000 \\
& & & & \\
Expected Tenure & 4.6 yrs & 5.1 yrs & 3.7 yrs & 4.3 yrs \\
Dissimilarity Index & 0.562 & 0.325 \\
\hline
\end{tabular}




\section{Table 8}

Probit Regression Results - Food Clerks

Determinants of Separation, 1978-1982

(Standard Errors are in Parenthesis)

\begin{tabular}{|lcc|}
\hline Variable & I & II \\
\hline Intercept & -0.109 & 1.651 \\
& $(0.059)$ & $(0.410)$ \\
Female & -.245 & -0.108 \\
& $(0.080)$ & $(0.100)$ \\
Age & -- & 0.001 \\
& & $(0.025)$ \\
Age ${ }^{2}$ & -- & 0.001 \\
& & $(0.0003)$ \\
Seniority & -- & -0.129 \\
& & $(0.023)$ \\
Seniority & & \\
& -- & 0.006 \\
Sample Size & 1,001 & $(0.001)$ \\
Log Likelihood & -670.87 & -638.79 \\
\hline
\end{tabular}




\section{Table 9}

Probit Regression Results - Food Clerks

Promotions to Store Level

Management Positions, 1978-82

(Standard Errors are in Parenthesis)

\begin{tabular}{|lcc|}
\hline Variable & I & II \\
\hline Intercept & -1.363 & -0.952 \\
& $(0.084)$ & $(1.063)$ \\
Female & -0.999 & -0.755 \\
& $(0.185)$ & $(0.217)$ \\
Age & -- & -0.018 \\
& & $(0.072)$ \\
Age ${ }^{2}$ & -- & -0.0001 \\
& & $(0.0011)$ \\
Seniority & -- & 0.096 \\
& & $(0.092)$ \\
Seniority & & \\
& -- & $(0.013$ \\
Sample Size & 1,001 & 1,001 \\
Log Likelihood & -161.21 & -155.46 \\
\hline
\end{tabular}


Figure 1

\section{Company Organization}

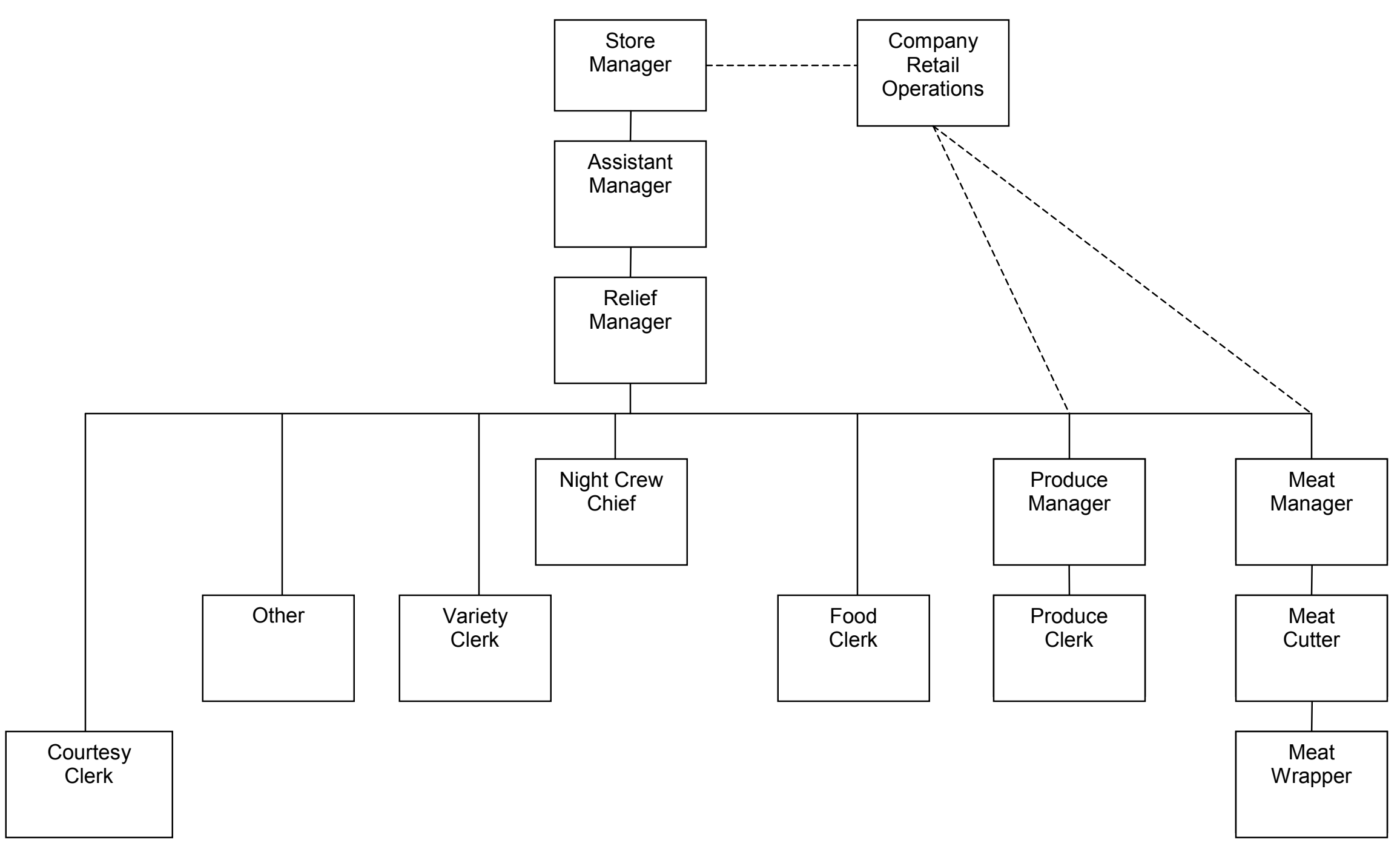




\section{IZA Discussion Papers}

\begin{tabular}{|c|c|c|c|c|}
\hline No. & Author(s) & Title & Area & Date \\
\hline 689 & $\begin{array}{l}\text { I. Haouas } \\
\text { A. Heshmati }\end{array}$ & $\begin{array}{l}\text { The Effects of Union Wage-Settings on Firms' } \\
\text { Production Factor Decisions }\end{array}$ & 5 & $01 / 03$ \\
\hline 690 & M. Hagedorn & Contracting with Private Information & 1 & $01 / 03$ \\
\hline 691 & $\begin{array}{l}\text { B. Petrongolo } \\
\text { C. A. Pissarides }\end{array}$ & Scale Effects in Markets with Search & 3 & $01 / 03$ \\
\hline 692 & $\begin{array}{l}\text { T. E. Smith } \\
\text { Y. Zenou }\end{array}$ & $\begin{array}{l}\text { Spatial Mismatch, Search Effort and Urban } \\
\text { Spatial Structure }\end{array}$ & 3 & $01 / 03$ \\
\hline 693 & $\begin{array}{l}\text { L. Gobillon } \\
\text { H. Selod } \\
\text { Y. Zenou }\end{array}$ & $\begin{array}{l}\text { Spatial Mismatch: From the Hypothesis to the } \\
\text { Theories }\end{array}$ & 3 & $01 / 03$ \\
\hline 694 & E. S. Prasad & $\begin{array}{l}\text { What Determines the Reservation Wages of } \\
\text { Unemployed Workers? New Evidence from } \\
\text { German Micro Data }\end{array}$ & 3 & $01 / 03$ \\
\hline 695 & $\begin{array}{l}\text { S. Alan } \\
\text { T. F. Crossley } \\
\text { P. Grootendorst } \\
\text { M. R. Veall }\end{array}$ & $\begin{array}{l}\text { Out-of-Pocket Prescription Drug Expenditures } \\
\text { and Public Prescription Drug Programs }\end{array}$ & 3 & $01 / 03$ \\
\hline 696 & R. Schettkat & $\begin{array}{l}\text { Institutions in the Economic Fitness Landscape: } \\
\text { What Impact Do Welfare State Institutions Have } \\
\text { on Economic Performance? }\end{array}$ & 3 & $01 / 03$ \\
\hline 697 & R. Schettkat & $\begin{array}{l}\text { Differences in US-German Time-Allocation: } \\
\text { Why Do Americans Work Longer Hours than } \\
\text { Germans? }\end{array}$ & 5 & $01 / 03$ \\
\hline 698 & $\begin{array}{l}\text { T. M. Andersen } \\
\text { J. R. Skaksen }\end{array}$ & $\begin{array}{l}\text { Product Market Integration, Comparative } \\
\text { Advantages and Labour Market Performance }\end{array}$ & 2 & $01 / 03$ \\
\hline 699 & $\begin{array}{l}\text { D. Margolis } \\
\text { V. Simonnet }\end{array}$ & $\begin{array}{l}\text { Educational Track, Networks and Labor Market } \\
\text { Outcomes }\end{array}$ & 2 & $01 / 03$ \\
\hline 700 & T. K. Bauer & $\begin{array}{l}\text { Flexible Workplace Practices and Labor } \\
\text { Productivity }\end{array}$ & 1 & $01 / 03$ \\
\hline 701 & $\begin{array}{l}\text { L. Goerke } \\
\text { J. B. Madsen }\end{array}$ & $\begin{array}{l}\text { Earnings-Related Unemployment Benefits in a } \\
\text { Unionised Economy }\end{array}$ & 3 & $01 / 03$ \\
\hline 702 & $\begin{array}{l}\text { M. Ayhan Kose } \\
\text { E. S. Prasad } \\
\text { M. E. Terrones }\end{array}$ & $\begin{array}{l}\text { How Does Globalization Affect the } \\
\text { Synchronization of Business Cycles? }\end{array}$ & 2 & $01 / 03$ \\
\hline 703 & $\begin{array}{l}\text { W. C. Horrace } \\
\text { R. L. Oaxaca }\end{array}$ & $\begin{array}{l}\text { New Wine in Old Bottles: A Sequential } \\
\text { Estimation Technique for the LPM }\end{array}$ & 6 & $01 / 03$ \\
\hline 704 & $\begin{array}{l}\text { M. Ransom } \\
\text { R. L. Oaxaca }\end{array}$ & Intrafirm Mobility and Sex Differences in Pay & 1 & $01 / 03$ \\
\hline
\end{tabular}

An updated list of IZA Discussion Papers is available on the center's homepage www.iza.org. 